\title{
PESANTREN IN THE CHANGING INDONESIAN CONTEXT: HISTORY AND CURRENT DEVELOPMENTS
}

\author{
M. Falikul Isbah \\ Universitas Gadjah Mada Yogyakarta, Indonesia \\ falikul.isbah@ugm.ac.id
}

\begin{abstract}
This article discusses the history of pesantren as an educational institution in the changing Indonesian context, and provides a snapshot on their current development and enrolment trends. It aims to provide an updated comprehension on Indonesian pesantren, which is an important aspect in understanding the contemporary development of Islam in Indonesia. The data presented here is based on a systematic review of existing literature and policy documents, interviews with key policy makers, and observation in some pesantren. I argue that Indonesian pesantren have continued to grow over different historical periods due to their adaptability in the changing contexts. Such adaptability is seen in their adoption of modern schooling system, their incorporation of non-religious subjects into their curricula, as well as their dynamic integration into the national education system.
\end{abstract}

Keywords: Pesantren, history, modernisation, education system. 


\section{A. Introduction}

Pesantren are Islamic boarding schools that have been found in Indonesia from pre-colonial times to the present. In the past, their core business was the provision of Islamic learning for Muslim pupils who had aspirations to later become the propagators of Islam in their home communities. In their current form and under the auspices of present and past Indonesian governments, pesantren have become an important part of the Indonesian national educational system serving a wide populace.

Kiai is a title given to Islamic scholars who for the most part provide the leadership of pesantren in Indonesia. Scholarship on Indonesian Islam has noted the important position of kiai in their communities, beyond their position as leaders of pesantren. The relationship between kiai and community is based on mutual expectation. Community members usually expect kiai to provide them with spiritual, moral, and religious guidance, as well as expecting them to perform a protective leadership role. In return, community members respect kiai, and out of this respect kiai gain the authority to disseminate Islamic teachings within the community. Beyond this local role, kiai also deal with outside agents on behalf of their community, as well as mobilising the community to support causes that the kiai advocate (Horikoshi, 1976, p. 300). In short, in addition to their position as pesantren leaders, kiai are expected to play multiple roles in important areas, which include Islamic rituals, Islamic propagation, politics and economics. The concerns and personal interests of individual kiai largely determine which of these multiple roles an individual will undertake. 
Until a decade ago, most studies on Indonesian pesantren and kiai are historical and anthropological. Scholars like Steenbrink (1986), van Bruinesssen (1990, 1994), Dhofier (1999), Azra (1994, 2006), Mas'ud (2004) and in some ways Abdullah (1986), just to mention the most widely read and cited, had cemented foundational bricks of this field for the next generations of scholars. Later generation brought the studies into a more topical emphasis like, among others, pesantren's role in education and shaping Muslim future generation (e.q. Hefner, 2009; Lukens-Bull, 2005; Tan, 2012), its involvement in electoral politics (e.q. Karim, 2008, 2009), and its dynamic as a religious authority (e.q. Halim, 2018; Pohl, 2006). Those works have provided in-depth explanation on the chosen topic. However, readers especially early scholars of Indonesian Islam have to read scattered sources to develop their understanding on this typical Indonesian Islamic learning institution. This article aimed at providing a short but wide-covering information on Indonesian pesantren, from historical information to contemporary development. It is expected to help readers with a "shortcut" reading before reading more historical, anthropological, and topical works on Indonesian pesantren.

Information and data used in this article were extracted from existing scholarly works, official information from authoritative organizations such as the Ministry of Religious Affairs and Nahdlatul Ulama in oral, written, accessed documents, and posted website news. The desk study was combined with fieldwork to fifteen pesantren in 2013 and follow up visits until recently. Available information on internet websites including the websites of the pesantren 
mentioned in this article has helped me to make crossreferences on certain information.

This article is organised into four sections. After this introduction, I will outline the history and shared characteristics of pesantren. The next section explores the changing learning model and curricula that has been the result of external influences from both the Dutch colonial education and Islamic reform movement that originated in the Arab world between the late $19^{\text {th }}$ century and the early $20^{\text {th }}$ century. The dynamic adaptation of pesantren learning model and curriculum formation in post-Independence Indonesia -which was a result of its gradual integration into national educational system- is discussed in the third section. The last section will examine the pesantren's current development and enrolment trends and situates the important role of pesantren in understanding the contemporary development of Islam in Indonesia.

\section{B. History and Shared Characteristics of Pesantren}

Pesantren are Islamic educational institutions that share many common characteristics. Their physical and organisational structures commonly share several elements: mosque, dormitory, students (popularly called santri), and kiai (Islamic scholar who leads pesantren). The central place is occupied by a mosque where the students and kiai pray five times a day, and do other activities that involve a large number of people, such as public lectures, collective prayers, and public preaching. The house of the kiai is commonly located beside the mosque and the dormitory where the students reside (Dhofier 1999: 34). Today's pesantren also 
commonly have class rooms and other school buildings. The other characteristic is the teaching of Islamic texts, organised mainly after prayer times.

In a more formal language, pesantren are commonly called pondok pesantren. Pondok literally means a 'hut', while pesantren means 'a place of the santri'. In a broader sense the term santri also refers to 'religiously oriented Muslims' as opposed to 'abangan' or nominal Muslims (Geertz, 1960b, pp. 121-130). The term 'santri' can also be limited to denote 'pesantren's student'. In the past, the term pondok pesantren or simply pesantren was used only in Java, but today the term pondok pesantren is also commonly used in other regions of Indonesia as this term has been adopted by the central government to refer to Islamic boarding schools (Azra, 2006, pp. 61-77). Nevertheless, some regions still use local terms to refer to similar institution such as surau in West Sumatera and dayah in Aceh. Surau literally means 'a place of worship' which is smaller than mosque, and is the same as langgar and mushalla in Java. In the Minangkabau region of West Sumatra, it denotes the site of traditional Islamic learning led by tuanku shaykh (Azra, 2003, 2006, pp. 63-68). In Aceh, the local name of similar institution is meunasah, rangkang, and dayah. Meunasah is a place in which children learn the recitation of al Qur'an and basic teachings of Islam, then they go to rangkang to continue with intermediate Islamic subjects, finally they end up in dayah as the most advanced level of Islamic schools. These schools are led by teungku (similar to kiai in Java) (Azra, 2006; Srimulyani, 2013).

Within a pesantren there is a central figure and authority who bear different titles according to locality. In 
Java, such figures are called kiai, in Sundanese ajengan, in Nusa Tenggara Barat tuan guru, in South Sulawesi guruta/ anreguruta. Other regions with strong Muslim populations have their own titles to refer to such figures. The authority of these figures is sometimes shared with other family members such as wife and sons who may also share an interest in managing the pesantren as an institution or in dealing with community affairs. As a central figure, the kiai is a role model and 'figurative parent' for the students. They consult him on problems related to pesantren and their daily life. In some pesantren in Java, a kiai is sometimes called romo, a Javanese word for father (Srimulyani, 2012, p. 43) or $a b a$, an Arabic word for father. In general, the relation of kiai and his students is not equal as he is believed to have superior intellectual and spiritual authority. This relation places kiai as the sole source of power and authority within the pesantren and no santri should question any decision made by him. Pesantren is therefore like a small kingdom led by the kiai. A kiai, as a source of knowledge and spiritual authority, is often visited by his students and the laity alike for consultation or to acquire his blessing (barokah) (see Dhofier, 1999, pp. 39-40). The other way to obtain such blessings is by inviting or asking a kiai to lead a collective prayer in a slametan for particular purposes such as celebrating a baby's birth, a wedding ceremony, and commemorating the death of family members (haul) (Bustami, 2009, pp. 53-60).

In addition to his specific role within his own pesantren, to some extent a kiai is also a central figure for surrounding community. Many kiai become leaders of mysticism order (tarekat) which organises systematic spiritual teaching with 
neighbouring communities and even attracts followers from faraway places (Mulyati, 2002; van Bruinessen, 1995).

The most widely shared legends about the origin of pesantren among ordinary Javanese Muslims are from the period of walisongo (nine saints) whom are believed to be the first propagators of Islam in Java and the teaching methods that they used to spread Islam in the Javanese community. These stories are still widely reproduced and disseminated at various events through religious sermons by Javanese Islamic preachers. Scholars, however, have debated the origins of the pesantren as an institution. Clifford Geertz (1960a, p. 231) has argued that pesantren are based on a model derived from Javanese Hindu-Buddhist monasteries from the second to the sixteenth century CE. When Islam came to the archipelago, the Islamic preachers maintained this educational model, but replaced its content with Islamic content, or in Geertz's words 'a new wine in a very old bottle' (Geertz, 1960a, p. 231). An alternative history has been suggested by Van Bruinessen (1994, p. 9), where he argues that today's pesantren developed in the nineteenth century as a further expansion of Islamic study groups located in mosques or the houses of kiai.

An Indonesian historian, Taufik Abdullah (1986, pp. 86-101) argued that the history of pesantren should be traced back to the period when 'religious men' withdrew from the life of kraton (the local name for the palace of Javanese kingdoms) because of internal political rivalries and disappointments with the kraton establishment and its dealing with European colonizers. This point is evident in the case of Diponegoro who was a prince of the Mataram Kraton in Yogyakarta. When he became disillusioned with the way the Kraton was 
dealing with the Dutch, he took his followers and established his own community in a village, whose political stance was more strongly anti-colonial and religious stance more overtly Islamic and that could be considered to be a 'religious or santri community'. The kiai with their santri community inhabited so called 'desa perdikan (autonomous villages)'. These were special villages that were established for religious purposes and given considerable autonomy and privileges, most notably tax exemption. With the deepening of Islam among the community, desa perdikan were then also characterised by the growth of Muslim cemeteries, mosques and pesantren. It is important to note that this historical pattern is specific only to Java (T. Abdullah, 1986; Azra, 2006, p. 72).

From the second half of the $19^{\text {th }}$ century onward, pesantren was a symbol of Islamic resistance and identity among the santri community. This can be seen from the reluctance of the santri community to send their children to the Dutch schools, which were beginning to be established from the end of the nineteenth century onwards. In the early part of the nineteenth century, there were 1,853 pesantren with 16,556 students. This number increased dramatically to 14,929 pesantren with 222,663 students by the end of the century, even though the Dutch schools had been introduced in many places. It seems that pesantren at that time were the choice for Muslims to maintain their independence and cultural pride in the face of increasingly intrusive Dutch colonial power (Azra, 2006, pp. 72-73).

Throughout the colonial era, the existence and development of pesantren was largely beyond the control of the colonial government. Instead, pesantren developed their 
own networks with Islamic learning centres in Egypt and present-day Saudi Arabia. The influence of the Arab world is evident in their curricula contents and models of education. Azra (1994), van Bruinessen (1994, 1995), and Mas'ud (2004) noted that most Indonesian pesantren were globally oriented in their intellectual reference and orientation. This can be found in their strong orthodoxy in using classical Arabic texts which might be brought or sent from Mecca or Medina from around 1600. The Arabic texts called kitab kuning are still used in pesantren until now. Van Bruinessen (1994) estimated that the use of kitab kuning in the East Indies had occurred before the existence of properly institutionalised pesantren. However, he could not estimate how wide its use was before the existence of pesantren educational tradition. The further development in Indonesian context was still consistent with the use of Arabic as a symbol of universal language of Islamic intellectual tradition, individual's intellectual integrity, and the language of Al Qur'an. The works of Indonesian ulama living in Mecca, such as Akhmad Khatib, Nawawi Banten and Kiai Makhfud Termas, and of those living in Indonesia such as Kiai Ihsan Jampes from Kediri also used Arabic. This type of pesantren was, and is, categorised as traditionalist pesantren.

Another type is pesantren modern. Beginning in the early 1900s, and connected to the flow of reform movement from the Middle East, there were some pesantren that called themselves pesantren modern or modern pesantren. The pioneer and still the most reputable of this type of pesantren is Pondok Modern Gontor in Ponorogo, East Java. It was founded in 1926 and combined the pedagogical philosophies of Al Azhar in Egypt, Aligarh and Santiniketan in India, and 
Taman Siswa in Yogyakarta. For the Gontor's founders, these educational institutions represented Islamic, modern, progressive, and anti-colonial pedagogical philosophies and spirit. They saw the existing old-style pesantren as being unstructured and undisciplined, and the government schools of the time as being part of the colonial agenda which oriented the schools towards producing colonial government's employees (Castle, 1966, pp. 30-32). The hallmark of this type of pesantren was their emphasis on the use of Arabic and English in daily conversation and learning activities. In theology and school of thought, they claimed not to be affiliated with particular schools of classical Islamic jurisprudence (madzhab). They saw a fanatical affiliation to certain schools of thought as contrary to the reform mission and as an obstacle to the development of Islamic scholarship. By taking this position, they accommodated children from both modernist and traditionalist streams of the population. Politically speaking, Gontor has always claimed to be neither affiliated to NU nor to Muhammadiyah by coining the tagline "untuk semua golongan or for all groups". Many of its graduates subsequently replicated this model in many other places such as Pesantren Pabelan in Magelang and Pesantren Darun Najah in South Jakarta. Currently there are more than 200 pesantren operated by Gontor's alumni and replicating the Gontor educational model. Pesantren Gontor also has a strong reputation, with many of its graduates becoming important political figures at national level (see Castle, 1966; Hady, 2012; Shabir \& Susilo, 2018; Yunus, 2008, pp. 276277). The examples of Gontor alumni on Indonesian national stage are Hasyim Muzadi, chairman of NU (1999-2010), Din 
Syamsuddin, chairman of Muhammadiyah (2005-2015), and Hidayat Nur Wahid, former chairman of Prosperity Justice Party (PKS) and Speaker of People Assembly (MPR, 20042009).

On the other hand, there are also some pesantren which have allegedly cultivated radical or Islamist ideas among their students. Radical or Islamist ideas here is Islamic ideology which is built on scriptualist understanding on the source of Islamic teachings to be applied in both private and public life. Muslims with such ideological view are categorised into wahabi-salafi group referring to the name of the founder of that movement Muhamad bin Abdul Wahab, and salafi word refers to their claim to be following the first generation of Muslims. One of the most well-known of these is Pesantren Al Mukmin in Ngruki near Solo, Central Java, under the leadership of Abubakar Ba'asyir. From the books that it uses, Pesantren Al Mukmin can be identified as being affiliated with the wahabi-salafi stream of Islam (Hasan, 2008; Tan, 2012 Chapter 3). The growth of new wahabi-salafi pesantren in Indonesia has been significant in the last decade (see Wahid, 2014). In addition, some pesantren are known for their specialities. Pesantren Suryalaya in Tasikmalaya with its famous leader Abah Anom is known for its focus on drug rehabilitation (see Mulyati, 2002).

Pesantren are not only limited to male students. Indeed, beginning in the early $20^{\text {th }}$ century, some pesantren started to accept female students. According to Srimulyani (2012, p. 38), Nyai Nur Khodijah and Kiai Bisri Syamsuri initiated an Islamic study group for girls in their Pesantren Denanyar in Jombang in 1919. Initially, only their close relatives and 
neighbours attended, but later this female study group attracted participants from distant places that led to the official establishment of a female dormitory in 1930 within the existing male-only pesantren complex. The opening of pesantren to female students then spread to other pesantren in Jombang. In 1929, Kiai Maksum Ali, who had previously helped Kiai Hasyim Asy'ari in Pesantren Tebuireng, opened a new pesantren for female students in a nearby village to Tebuireng called Pesantren Putri Salafiyah Syafi'iyyah (Yasin \& Karyadi, 2011, pp. 12-13; Zaini, 1998, pp. 54-66). In West Sumatera, Rahmah Al Yunusiah founded Madrasah Diniyah Putri in Padang Panjang in 1923 (Yunus, 2008, p. 69). All these female pesantren continue to exist today. Currently, most pesantren accommodate both male and female students along with the widespread involvement of women in the provision of pesantren education.

Viewed historically, the growing trend of women's participation in education initially started at the beginning of the $20^{\text {th }}$ century when the Dutch colonial government implemented Ethical Policy, which opened up opportunities to the indigenous people, both male and female, to enrol in Dutch colonial schools. In practice this opportunity was provided for the aristocratic layer of society, especially in Java. Early women proponents of women education such as Kartini of Jepara and Dewi Sartika of Bandung appeared in this period. Later, those educated and literate women agitated for wider access to education that would encompass a broader layer of the female population. This trend also influenced Islamic organisations like Muhammadiyah and Nahdlatul Ulama. Kiai Ahmad Dahlan, the founder of Muhammadiyah, together with 
his wife initiated an Islamic school for girls, which was later named Madrasah Muallimat Muhammadiyah in Yogyakarta. At the same time, the organisation also established an organisational wing, Aisyiah, to provide greater opportunities for women's involvement within Muhammadiyah. Around the same time, there were several traditionalist pesantren which began to receive female students. This coincided with the establishment of NU's women organisational wing, Muslimat NU (Srimulyani, 2012, pp. 37-39). Female pesantren have become important in the production of women leaders for Islamic women's organisations, female politicians in Islamic parties, and female Muslim scholars and public intellectuals in Indonesia.

While the historical background of the foundation of most pesantren often centred on the central initiative of an individual kiai and support from surrounding community, from 1990s we can find other models of pesantren foundation. Firstly, some media-star preachers have founded pesantren and use them as the base of their activities. For example, Kiai Haji Abdullah Gymnastiar or popularly called AA Gym founded Pesantren Darut Tauhid in Bandung, West Java and has used it as a centre for various activities, ranging from workshops, regular sermons, to being a basis for business activities. Unlike other pesantrens where students are resident, Pesantren Darut Tauhid does not have any permanent residential students. Groups of people will stay at the Pesantren only for a short time (such as a weekend, three days or a week) for workshops with planned programs. This pesantren does not have a school as is the norm for other pesantren (Solahudin, 2008; Watson, 2005; my personal observation, October 2008). As 
such, Pesantren Darut Tauhid presents a new model for what Indonesians calls pesantren. Another celebrity preacher who has founded a pesantren is Ustadz Yusuf Mansur. He founded Pesantren Tahfidz Daarul Qur'an (Pesantren for Memorising Al Qur'an) in Tangerang, Banten. Unlike AA Gym's Pesantren which does not accommodate permanent residential students, Pesantren Tahfidz Daarul Qur'an has residential students who follow a special program of memorising Al Qur'an.

There is a second category of pesantren that have been founded by wealthy families as in the case with Pondok Pesantren Modern Islam Assalam near Solo, Central Java. The family of Haji Abdullah Marzuki and Siti Aminah are successful local entrepreneurs and who own a printing company and book store, Tiga Serangkai. As they are not qualified religious teachers, the family hires Islamic teachers to operate the pesantren and the family remains as the patron of the institution. The Pesantren Assalam was known to charge very high fees, more than Rp. 16 million for the enrolment in 2013 and approximately Rp. 2 million for monthly fees (www. assalam.or.id).

There is a third category of new pesantren development that centres on pesantren founded as initiatives from networks of preachers and mosques care-takers in Makassar city. This is the case with Pesantren Modern IMMIM in Makassar, South Sulawesi. IMMIM is an acronym for Ikatan Masjid Musholla Indonesia Muttahidah (Association of Indonesian Mosques and Prayer Halls), a Makassar-based local network of mosque care-takers and preachers. One of the aims of this organisation is to strengthen unity and diminish differences- which mostly concerns aspects of ritual (furu')- among Muslims. As 
such, the foundation of the Pesantren IMMIM was an effort to produce high quality Islamic preachers with a strong capacity to work across the divided communities- such as who affiliated to Muhammadiyah, Nahdlatul Ulama, and other groups (Damopoli, 2011).

A fourth category can be seen with the establishment of Pesantren Hidayatullah in Balikpapan. This Pesantren represents a different organisational background: it is a learning centre for preachers recruited by the Hidayatullah as mass-organisation. The Pesantren Hidayatullah was founded in 1976, and transformed into an Islamic mass organisation (Ind. ormas) in 2000 to manage networks of da'wah cadres graduating from the Pesantren. Currently, the organisation manages da'wah activities throughout the archipelago especially in remote areas and has branches in 200 municipalities. In order to fulfill demand for preachers, the Hidayatullah educates and trains hundreds of cadres in its Pesantren at no cost. After graduating, these cadres will be sent to various remote places on propagation missions (Burhanuddin \& Basri, 2003; Subhan, 2006; my personal observation, September 2013).

Prior to Hidayatullah, there had been some pesantrens which had been turned into mass organisations such as $\mathrm{Al}$ Khairat in Palu, Central Sulawesi and As'adiyah in Wajo, South Sulawesi. Similarly, this transformation was further developed by their scattered alumni who in turn founded new pesantren and Islamic schools in their home towns. However, their development seems to be limited to pesantrens in surrounding regions. For example, Pesantren Darul Da'wah wal Irsyad (the Centre for Propagation and Spiritual Guidance, 
DDI) in Mangkoso, South Sulawesi transformed into a mass organisation whose followers are concentrated mainly in the same province and in places where the local Bugis people have migrated such as Papua and East Kalimantan. The Pesantren was founded in December 1938 under the leadership of Abdurrahman Ambo Dalle. When some of its graduates returned to their home towns or migrated to new places, they also founded pesantren or Islamic schools. Abdurrahman Ambo Dalle allowed them to use the name ofDDI. Along with the spread of these Islamic educational institutions, they initiated the transformation of the network into a mass organisation during the early independence period of the country. Their purpose was to strengthen their $d a^{\prime}$ wah outreach, especially through the establishment of Islamic schools. Currently under this organisation there are more than 200 Islamic schools scattered in eight provinces, but mostly in South Sulawesi and West Sulawesi (my fieldwork, September 2013).

In a similar way, Pesantren Nahdlatul Wathan Diniyah Islamiah founded in 1937 in Pancor, East Lombok has also been transformed into an influential mass organisation named Nahdlatul Wathan (NW) in West Nusa Tenggara province. Its history goes back to Tuan Guru Zainuddin who returned to his home town in East Lombok after studying in Mecca for 12 years. The Pesantren has produced Islamic scholars and community leaders who have transmitted the Islamic teachings of Tuan Guru Zainuddin to broader regional community through the establishment of Islamic schools and $d a^{\prime}$ wah activities. Up until 2000, there were 377 Islamic schools, ranging from kindergarten to senior high school, that have been affiliated to this organisation (nw.or.id). 
The last type of pesantren I present is a pesantren which was founded by a business motivator Jamil Azzaini who is obsessed with the idea of creating young entrepreneurs with strong da'wah commitment. The Pesantren named Abdurrahman bin Auf does not provide a normal learning track through schooling as is the case with other pesantren. It provides instead a year-intensive life skill training in fields such as livestock, agribusiness, computer repair and so forth that are imbued with Islamic psychological motivation. The students come from poor households who are unable to continue their studies to higher levels and are unable to find jobs. With the skills studied in the Pesantren, they are expected to be able to create their own businesses after their year-long study there (jamilazzaini.com).

Based on these examples I argue that pesantren are still considered important Islamic educational institutions, that produce an Islamic learned generation who are expected to sustain Islam among the wider Indonesian community. For celebrity preachers, founding and leading a pesantren can add legitimacy to their religious authority. For wealthy people, devoting their wealth to the establishment of a pesantren can be a way to spend their wealth in an Islamic mission. For a promoter of da'wah, pesantren might be considered to be the most effective educational model to produce $d a^{\prime} w a h$ cadres. For a motivator of entrepreneurship, the provision of intensive life skill training complemented by an Islamic motivation within pesantren might be seen as a comprehensive means to transform individuals into highly motivated entrepreneurs.

The last point I highlight in this section concerns leadership transfer. The leadership transfer in most 
traditionalist pesantren that are often affiliated to Nahdlatul Ulama is hereditary. When the leader dies, one of his sons or sons in-law (only men can become leaders in most cases) will take over the leadership automatically or as the result of a family convention. In such cases, subsequent development of the pesantren depends on the capacity of the new leader. In some cases, pesantren deteriorate or even close down because their new leaders do not have the reputation or charisma to attract students. By way of contrast, pesantren which are subsequently transformed into a mass organisation are likely to manage their leadership transfer through organisational meeting such as was the case with Pesantren Darul Da'wah wal Irsyad (the Centre for Propagation and Spiritual Guidance, DDI) and Pesantren Asádiyah in South Sulawesi, and Pesantren Hidayatullah in Balikpapan. There are other pesantrens that have established a board of patrons called Badan Wakaf whose job it is to appoint (or dismiss) the pesantren's leader, as was in the case with Pesantren Gontor in Ponorogo, East Java and its networks. In practice, however, the appointed leaders still share a 'bloodline' with the pesantren's founders or previous leaders.

\section{Learning Models and Curricula}

The learning model in pesantren has gradually been reformed as a result of influences from both Islamic learning tradition in the Arab world and a Western schooling model brought by the Dutch to the country. In pre-independent Indonesia, the learning model in pesantren was very modest. A kiai read the kitab kuning (classic books) surrounded by his students, and sometimes complemented this with a question 
and answer season. There was no systematic grading system. When student numbers were large and their intellectual levels were diverse, the kiai organised the learning process but delegated the teaching task for some groups to his senior students. This model was changed by Muslim scholars who had returned from their studies in Egypt in early 20th century. At this time the Islamic reform movement was taking place in Arab countries in response to colonialism and the identified backwardness among Muslims, especially in the fields of science and technology (Steenbrink, 1986, p. 26). According to Muhammad Abduh, one of the most important figures of the Islamic reform movement, this backwardness was a result of the separation of school into those Islamic schools which taught only Islamic subjects and the modern schools which taught non-religious subjects. This separation created two distinct cohorts with different visions regarding the future of Muslim ummah (Hourani, 1983, p. 137). At the same time, during the late 19th century, the Dutch also began to introduce schooling for selective segments of indigenous population. Some years later, some of the graduates of these Dutch schools taught in pesantren where they passed on their experiences in the Dutch school system. Those two developments-Islamic reformism and colonial, Western education-gradually influenced the pesantren world. The first influence evidenced in the adoption of graded classes of madrasah system, and the second was the incorporation of non-religious subjects (Steenbrink, 1986, p. 25). This new model was initially adopted by some Muslim reformists after studying in Middle East, especially at Al Azhar University in Cairo. Later, however, the traditionalists also began to follow 
this trend (Azra, Afrianty, \& Hefner, 2007, pp. 175-177; Dhofier, 1999 Chapter Four; Steenbrink, 1986, pp. 69-72; van Bruinessen, 1994, pp. 20-24).

Madrasah is an Arabic word for school, while sekolah is an Indonesian word derived from Portuguese to refer to school. In the Indonesian context, madrasah are specifically Islamic schools supervised by the Ministry of Religion. Meanwhile, sekolah denotes non-religious schools supervised by the Ministry of Education. The hierarchical structure of madrasah ranges from Raudlotul Athfal (RA) for kindergarten, Madrasah Ibtida'iyah (MI) for primary level, Madrasah Tsanawiyah (MTs) for secondary level, and Madrasah Aliyah (MA) for higher levels. The hierarchy of sekolah ranges from Taman Kanak-kanak (TK) for kindergarten, Sekolah Dasar (SD) for primary level, Sekolah Menengah Pertama (SMP) for junior secondary level, and Sekolah Menengah Atas (SMA) for senior secondary level. With these two structures, it can be said that Indonesian national education system covers both madrasah and sekolah system.

In terms of educational arrangement, today's pesantren can be divided into three main categories. The first category is pesantren kholaf that provide formal schooling through madrasah and sekolah. The second category is pesantren salaf (not salafi) which do not provide a government-approved schooling system (Hefner, 2009, pp. 66-69; Lukens-Bull, 2005; Zuhdi, 2006). Such pesantren still exist in some places and are regarded as able to produce graduates with greater expertise in kitab kuning as they do not need to study general sciences (Isbah, 2012). The final category is pesantren modern which is often distinguished by their emphasis on the teaching 
of Arabic and English and the obligation of students to use these languages in their everyday conversations. The first pesantren using this brand was Pesantren Modern Gontor in Ponorogo, East Java. Later, Gontor's alumni went on to found new pesantren in many other places, and have copied its educational model and use the brand 'modern' as well.

Today, the majority of pesantren provide formal schooling through madrasah and sekolah that incorporate non-Islamic subjects in their curricula like any other school, and can be categorised as pesantren kholaf. The difference is that pesantren schools provide a greater proportion of Islamic subjects in their curricula than is the case with schools outside pesantren system. Given the limits of school hours, most pesantren arrange their curricula so that Islamic subjects and the teaching of kitab kuning are given outside the school hours, commonly in afternoon or evening through a madrasah diniyah, halaqoh (discussion group) and pengajian. In madrasah diniyah, the management and teaching methods are similar to secular school, but the material is limited to Islamic teachings which commonly stresses Arabic, theology, Islamic law (fiqh and ushl fiqh), Islamic ethics (akhlak), tasawuf(mysticism), Qur'anic exegesis (tafsir), and Traditions of the Prophet (hadits) (van Bruinessen, 1995, pp. 32-37). Such decisions were an adaptation of pesantren world to the public demand for state registered formal schooling, while simultaneously being an effort to maintain their learning traditions.

In terms of Islamic subjects taught in pesantren, there is a difference between what so called modernist/reformist pesantren and traditionalist/classicalist pesantren teach 
(Lukens-Bull, 2005, p. 14). The modernists or reformists are generally associated with the Muhammadiyah, Persatuan Islam, Al Irsyad or other newly established wahabi-salafi groups. The traditionalists or classicalists are mostly associated with Nahdlatul Ulama (NU) and other locally based smaller groups such as Mathlaul Anwar which is popular in some regions of West Java, Nahdlatul Waton which is popular in West Nusa Tenggara, and Al Khairat which is popular in Central Sulawesi and some regions of eastern Indonesia.

A part from the differences between the modernist and the traditionalist lies in the way they understand Islamic doctrines and their attitudes to certain religious practices, especially relative local customs. Generally speaking, the traditionalists are more accommodative to local customs. As for pesantren education, the traditionalists treat the historical development of Islamic sciences that have been codified in kitab kuning as their primary reference. Kitab Kuning are a range of books that were mostly written between $10^{\text {th }}$ and $15^{\text {th }}$ century. For traditionalist Muslims, they are accepted as the final intellectual work that cannot be supplanted by new works, but may be explained only in a more detail in such subsequent works. Kitab literally means book, and kuning literally means yellow. Those books are called kitab kuning because they are printed on yellow paper (van Bruinessen, 1995, pp. 17-30). In contrast, the modernists tend to ignore books in the kitab kuning tradition and instead focus mainly on the study of al Qur'an (under the subject of ilm tafsir and ulumul Qur'an) and hadist (Traditions of the Prophet).

In line with the wider adoption of a government approved madrasah schooling model since early 1970s, 
many pesantren started to incorporate non-Islamic subjects in their curricula. It should be noted, however, that Islamic schools managed by Muhammadiyah were among the first to introduce subjects like mathematics, geography, Dutch language and so forth, while Pesantren Tebuireng in Jombang was among the first traditionalist pesantren to do the same thing in late colonial era (Dhofier, 2011, p. 186). According to Lukens-Bull (2000, p. 26, 2001), combining Islamic and non-Islamic subjects in their curricula was the way pesantren leaders encountered modernisation and globalisation. In this way, they were projecting their students on a path to become members of a society "that is fully modern, fully globalised, fully Indonesian, and fully Islamic" at the same time (LukensBull, 2000, p. 26).

\section{Modernisation and Integration into the Indonesian Educational System}

In post-independence Indonesia, pesantren have gradually gained state recognition through their integration into the national educational system. In the early years of independence, the government recognised the existence of Islamic schools - pesantren and madrasah-and placed them under the supervision of the Ministry of Religious Affairs rather than the Ministry of Educational Affairs. This policy created a duality in the management of educational affairs. The passing of the National Education Law in 1952 regulated the schools under the supervision of the Ministry of Education only. It left the Islamic schools out of the national education system. The New Order regime which took over the country in 1966 attempted to integrate both secular and religious schools 
under one ministry, the Ministry of Education. This attempt was made through the implementation of 'single umbrella education' (pendidikan satu atap) policy that was based on a Presidential Instruction in 1972. However, many Muslim educators could not accept this policy as they considered it to be an over-simplification over the problem on the ground, and they were suspicious that the actual purpose of the regime was to eliminate the existence of Islamic schools. Instead, they proposed the idea of standardising curriculum of Islamic schools. This was eventually adopted in the so called 'ThreeMinistry Joint Decree' (SKB 3 Menteri). The main point in this policy was that Islamic schools had to adopt a curriculum where 30 percent of learning hours was devoted to religious subjects and 70 percent to non-religious subjects (Zuhdi, 2006, pp. 417-421)).

Since 1975 , and partly due to the implementation the Three-Ministry Joint Decree, the general tendency in most pesantrens has been to follow the model of the state's educational system and its curricula. Pesantren manage their schooling through government-recognised madrasah system which requires 70 percent of its learning hours for nonIslamic subjects and the rest 30 percent for Islamic subjects (Hefner, 2009, p. 65). In addition, they provide instruction in a more diverse range of Islamic subjects in lessons out of school hours. Most pesantren today organize their Islamic subject teaching in madrasah diniyah which they hold in the afternoon or evening. This educational model can be found in many prestigious pesantren like Pesantren Tebuireng and Pesantren Darul Ulum in Jombang, East Java. These two pesantren also have established universities in their complexes with various 
departments that range from English, Education, Psychology, to Law. One reason for this is to equip their graduates with modern skills and degrees so that they are able to compete in the modern labour market. Consequently, graduates from these institutions can readily be found working in government offices, universities, the business sector, and, of course, religious offices (Hefner, 2009, p. 66). In short, it seems that such pesantren do not consider themselves to be different from general schools, except in their commitment to provide a greater range of Islamic subjects and the pesantren living experiences. However, the broad policy remains of keeping madrasah under the supervision of the Ministry of Religion, while sekolah (non-religious schools) are under the Ministry of Education.

After the fall of Soeharto's regime in 1998, pesantren moved to become more closely integrated into the national educational system. The most recent National Education Law of 2003 recognises fully that pesantren and madrasah are part of the country's educational system. Government Bill No.55 of 2007 (PP 55/2007) on Islamic Education strengthens the law by stating that students from Islamic schools are entitled to transfer to any other school and that the graduates of these Islamic schools are entitled to a state recognised certificate which can be used for both job applications and higher school/university entry requirements. Another important policy of the post-New Order Indonesian government related to pesantren was the elevation of the Sub-Directorate of Pondok Pesantren and Madrasah Diniyah in the Ministry of Religion to be a directorate in 2001. This policy has provided the Directorate with more chances to secure greater state 
funding and to gain greater authority (Interview with Ace Saifudin, Director of the Pondok Pesantren and Madrasah Diniyah, Ministry of Religious Affairs, Jakarta, 18 May 2013).

As a consequence of these changing policies and the internal dynamic within pesantren world in responding societal changes, the educational model of Indonesian pesantren today can be divided into four categories. The first is pesantren salaf (traditional) which provides only Islamic teachings in the form of classical works (i.e. the kitab kuning (classic books on Islamic sciences mentioned above). Pesantren of this type commonly organize their teaching activities in madrasah diniyah and pengajian bandongan (public lecture). The second are pesantren that build formal Islamic schools in the form of madrasah ibtida'iyyah (primary school), madrasah tsanawiyyah (junior high school), and madrasah aliyah (senior high school/college) that are supervised by the Ministry of Religious Affairs. Their curriculum is determined by the Ministry in the form of modern text books which are changed periodically. A number of large pesantren have also established tertiary education institutions (perguruan tinggi) within their complexes. The third type of pesantren is similar to the previous type, but their schools are affiliated to the Ministry of National Education and are regarded as sekolah or secular schools, not madrasah. The fourth kind are pesantren that provide both madrasah and secular schools (Bustami 2009: 39). Except the first type, all are categorised as pesantren kholaf (as opposed to pesantren salaf). Many pesantren today organize formal education in madrasah or secular school classes in the morning and teach kitab kuning in the afternoon and evening. This is their way to adapt to modernisation and to meet the expectations of students and 
parents seeking formal certification (Azra et al., 2007; Hefner, 2009; Steenbrink, 1986; Zuhdi, 2006).

The fact that the majority of today's pesantren resemble the pesantren kholaf model can be seen as a response to parents' pragmatic demands that education be an important contributing factor to students' economic success. Unfortunately, there is no official data available that compares the number of each type of pesantren. Many pesantren opened madrasah or general elementary schools with nonreligious and vocational subjects in the 1970s and 1980s. Their residential students attend these madrasah during the morning and spend the afternoons and evenings studying religious subjects in the dormitory. It is also important to note that all pesantren are independent institutions, and none of them are funded by the Indonesian government. A 2005 data from the Ministry of Religion reveals that 47 percent of pesantren are operated by private foundations, and 39 percent by individuals. The reminder is run by Islamic mass organizations such as Muhammadiyah, Nahdlatul Ulama or other organizations (Jackson \& Parker, 2008, p. 26).

There is strong pressure on all forms of Indonesian Islamic education, including pesantren, to integrate into the national education system. However, according to Jackson and Parker (2008), pesantren have constantly faced an uneasy adjustment to, and negotiation with, government policy and its values. For example, in order to produce graduates who are able to compete with their counterparts from secular schools both in the labour market and in pursuing higher education, Islamic schools, including pesantren schools, have to allocate large proportion of their teaching hours to 
non-Islamic subjects. Added to this, they have to maintain an appropriate number of hours for Islamic subjects in their curriculum. The other issue is that the national education system encourages active and participatory teaching and learning methods in order to raise the level of students' critical thinking. In contrast, this traditional Islamic education method is generally teacher-centred with a high degree of respect for a teacher's knowledge and authority, and tends to centre on rote learning. This might give rise to a contradiction in pedagogical approaches. In summary, most of them have tried to be adaptable to the educational system endorsed by the state (Azra et al., 2007; Hefner, 2009; Zuhdi, 2006).

\section{E. Current Development of Pesantren and their} Enrolment Trends

The current growth of Indonesian pesantren and their enrolment trend is complex. Statistically the number of pesantren has been increasing steadily over the past decades, but their proportion of the total national student body remains at only about 13 percent of Indonesian school age children (Azra et al., 2007, pp. 178-180). Some commentators have sought to justify the importance of pesantren not merely in terms of their student numbers relative to that of general schools but in terms of the strategic position that pesantren hold in driving the direction of Islam in a country where there are many contested sources of religious authority in Indonesia (cf. Sakai, 2012, 2014). My own observation additionally suggests that there is a new tendency among those who do not have pesantren education background but now wish to send their children to pesantren. 
Number of Pesantren and Pupils (1977-2012)

\begin{tabular}{ccc}
\hline Year & $\begin{array}{c}\text { Number of } \\
\text { Pesantren }\end{array}$ & $\begin{array}{c}\text { Number of Pesantren } \\
\text { Pupils }\end{array}$ \\
\hline $2016 \mathrm{~d}$ & 28,194 & $4,290,626$ \\
\hline $2011-2012 \mathrm{a}$ & 27,230 & $3,759,198$ \\
\hline $2006-2007 \mathrm{~b}$ & 17,506 & $3,289,141$ \\
\hline $1997 \mathrm{c}$ & 9,388 & $1,770,760$ \\
\hline $1977 \mathrm{c}$ & 4,195 & 677,384 \\
\hline
\end{tabular}

Source: (c. Azra et al., 2007; b. Direktorat Jenderal Kelembagaan Agama Islam, 2008; a. Direktorat Jenderal Pendidikan Islam, 2012a; d. Muhyiddin \& Yulianto, 2017)

A report based on a survey in 2011-2012 from the Ministry of Religious Affairs showed that the number has reached 27,230 pesantren which accommodate 3,759,198 students (Direktorat Jenderal Pendidikan Islam, 2012a). This is a remarkable growth if we trace back to data published in previous years. For example, in 2006-2007, the pesantren number was 17,506 with 3,289,141 students (see Table 1 The table above). It is not known why the number of pesantren had increased and why student number have not shown a proportional increase. This might relate to a growth in the establishment of new pesantren in many places. These new pesantren need time to build a reputation and to attract students. There is no longer a gender gap between male and female students with $50.19 \%$ of them male and 49.81 percent female. Unfortunately, there was no available data on the gender comparison and gap in pesantren's enrolment figures across different years. The majority of students (79.93\%) live in pesantren's dormitories, while only $20.07 \%$ live with 
their parents or in rented accommodation outside pesantren complex (Direktorat Jenderal Pendidikan Islam, 2012a).

Unfortunately, there was no available information of what the percentage of those figures against the total number of Indonesian school age children. Azra, Afrianty, and Hefner (2007, pp. 178-179) suggested that in 2001-2 pesantren educated about $13 \%$ of the total school age children. However, there was no data across different years.

Throughout my visit to about fifteen pesantren in various regions during my research, however, I found evidence that supports the increasing enrolment in pesantren. For instance, Pesantren Sunan Pandanaran di Yogyakarta now accommodates 3000 students, while it accommodated only 600 students prior to 2005. Likewise, around 5000 students now reside in Pesantren Sunan Drajat in Lamongan, East Java that is doubling of the number of 10 years ago. All these pesantren are complemented with formal madrasah schooling model where the graduates receive certificates that enable them to pursue higher education. By way of contrast, a stagnant or declining enrolment trend can be found with pesantren salaf such as Pesantren Lirboyo in Kediri, East Java and Pesantren Sarang in Rembang, Central Java, which do not have formal madrasah schooling model. Without a systematic survey, we cannot make any generalisation from this trend. I found, for example, Pesantren Salaf Sidogiri in Pasuruan, East Java displays a trend towards slightly increasing student enrolment over the last 5 years and is becoming more popular among neighbouring communities (see Isbah, 2012, 2019). After the enactment of Government Bill number 55 on Religious Education in 2007, the graduates of such pesantren 
salaf are actually able to continue to any type of school and university. Nonetheless, a large segment of Muslims may perceive that such pesantren as not modern and, therefore, less relevant to worldly demands.

In general, the tuition fees of pesantren are relatively lower than those of government schools despite the greater government subsidy that the latter receive. Because studying in pesantren as residential student (santri) requires payment of not only tuition fees but also living expenses, parents have to send more money to their children in pesantren. In spite of this, 85 percent of the parents of pesantren's students had income of less than Rp. 500,000 per month or Rp. 16,500 (USD 1.75) per day, putting them below the poverty line of USD 2 per day (Jackson and Parker 2008: 26). After the regime changed in 1998, there has been an increasing government budget allocation for Islamic schools including pesantren. What is the impact of the current government subsidies on the institutional development of pesantren and their relation with the wider community? Based on a quantitative research on three different types of pesantren modern cum modernist pesantren, semi-modern pesantren, pesantren salaf- and a secular public school, Sticher (2008) presents the following findings: First, parents who send their children to pesantren salaf are likely to have lower educational level compared to those sending their children to modern or semi-modern pesantren, and even more so to secular public school. Second, most parents of pesantren salaf are likely to have been to pesantren themselves. The number of parents who attended a pesantren decreases at each step for those who send their children respectively to semi-modern pesantren, modern 
pesantren, or to secular public schools. Third, students/ santri of pesantren salaf have more siblings (from 2 to 13) than those of semi-modern and modern pesantren, and even more than for secular public school students (Sticher 2008: 157-64).

Based on these quantitative findings, Sticher (2008, pp. 162-165) argues that choice of a school is linked closely to the educational background of parents, their own pesantren experience, their family size, and economic level. Educational attainment and family size are also indicators of social class. This data shows that parents of pesantren salaf's students are mostly from lower class backgrounds relative to other kinds of pesantren and secular schools. There are two possible explanations for this. First, it is because pesantren salaf are cheaper than their alternatives. However, this reason is certainly not or no longer accurate because today secular public schools or pesantren with government recognised madrasah -as in the case of modern and semi-modern pesantren- may be cheaper than in the past as a result of government subsidies. Financial reasons are, however, likely to be just a part of the explanation. Another reason is that well-educated parents, especially those with secular educational backgrounds, prefer secular schools or pesantren with secular subjects.

In terms of quality which can be measured by failure rates in National Final Examination, pesantren or madrasah are relatively less successful than secular schools. The available data of 2003 indicates that the failure rate at junior secondary madrasah (Tsanawiyah) is $10.9 \%$ compared to 3.9 $\%$ at general junior secondary school. For senior secondary madrasah (Aliyah), the failure rate is $15.4 \%$ compared to 
$5.7 \%$ at general senior secondary school. This is because they tend to serve disproportionately a rural and poor demographic (Azra et al., 2007, pp. 177-182). Azra, Afrianty, and Hefner (2007, pp. 177-182) showed a statistic produced by the Ministry of Religious Affairs in 2003 suggesting that over $50 \%$ of pesantren students were children of farmers or laborers. A survey in 1999, across ten provinces, indicated that $85 \%$ of pesantren are located in rural areas, $14 \%$ in semi-urban districts, and just $0.8 \%$ in cities (Azra et al., 2007, pp. 177-182). The most current data from 2012 suggests a similar success rate of $99.45 \%$ for both Madrasah Aliyah and secular high school (SMA) (M. Abdullah, 2019; Amrulla \& Zuhri, 2013). For secondary schooling, the success rate is $99.57 \%$ for secular junior secondary school (SMP), but there is no available data on the success rate for Madrasah Tsanawiyah only. The available data does not disaggregate the data for SMP and Madrasah Tsanawiyah (Direktorat Jenderal Pendidikan Islam, 2012b; Kumoro, 2012).

The success rate in the National Final Examination as a reliable indicator of the educational quality should be questioned, as there is a substantial amount of mass media reporting, which questions the integrity of this examination, due to practices such as cheating, the leaking of question and answer sheets, and an over emphasis on coaching for the examination by teachers who fear the possible failure of their students in this examination.

\section{F. Conclusion}

As an Islamic institution, pesantren has played several important and crucial roles in the changing historical situation 
of Indonesia. It has survived different political contexts and continued to grow despite the changing socio-economic conditions of Indonesian people. In the colonial era, it tried to isolate itself from the influence of the European, non-Muslim, colonizers because they believed that the Islamic learning tradition would nurture a mastery in Islamic sciences and through this Muslims would be able to perform their religious obligations in line with the Islamic orthodoxy. Pesantren leaders saw a different goal in the colonizers' educational philosophy which was perceived as a worldly oriented system. Such a philosophy was regarded harmful to the 'pure vision' of pesantren learning tradition. As a result, pesantren education represented a solid block to the influence of the colonizers. Pesantren leaders maintained and developed an intellectual network with Islamic learning centres in the Arab speaking world through pilgrimage to Mecca and by studying in the Middle East.

Over the course of the late $19^{\text {th }}$ century, the situation changed when traditional Islamic education in the Middle East was subject to a reform movement. This reformism was a result of self-critique on the backwardness of Islamic society throughout the world. One of the ways advocated to overcome this backwardness and to enhance the progress of Muslims was that Islam -and Islamic education in particular- should adopt aspects of Western notions of modernity. It resulted in the adoption of graded class model to replace halaqah model which had previously been the most popular. Another result was the incorporation of non-Islamic subjects as to equip students who were facing a competitive modern world. This reform greatly influenced pesantren in Indonesia, as 
evidenced by their adoption of graded class model in the form of madrasah system and the incorporation of non-Islamic subjects.

Later, the government of post-independence Indonesia put pressure on pesantren, so that they would be in line with national development priorities by integrating them into national education system. Up until the present, there has been a dynamic negotiation and appropriation in the process of interaction between the Indonesian state and pesantren as independent entities, particularly with regard to curriculum content and the portion of Islamic subjects in it. In spite of its weaknesses as an educational institution, pesantren have continued to grow and play significant roles in maintaining the Islamic educational tradition, out of which considerable numbers of Islamic scholars and community leaders have been produced. Therefore, understanding pesantren remains important way of understanding the development of Islam in Indonesia.

\section{REFERENCES}

Abdullah, M. (2019). School culture to serve performance of Madrasah in Indonesia. Qudus International Journal of Islamic Studies, 7(1), 71-100. https://doi. org/10.21043/qijis.v7i1.4572.

Abdullah, T. (1986). The Pesantren in Historical Perspective. In T. Abdullah \& S. Siddique (Eds.), Islam and Society in Southeast Asia. Singapore: ISEAS.

Amrulla, A., \& Zuhri, D. (2013, September 22). Ribuan Madrasah Belum Terakreditasi. Republika. 
Azra, A. (1994). Jaringan Ulama: Timur Tengah Dan Kepulauan Nusantara Abad XVII Dan XVII: Melacak Akar-Akar Pembaruan Pemikiran Islam Di Indonesia. Bandung: Mizan.

Azra, A. (2003). Islam in the Indonesian World: An Account of Institutional Formation. Jakarta: Logos Wacana Ilmu.

Azra, A. (2006). Islam in the Indonesian World: An Account of Institutional Formation. Bandung: Mizan.

Azra, A., Afrianty, D., \& Hefner, R. W. (2007). Pesantren and Madrasa: Muslim Schools and National Ideals in Indonesia. In R. W. Hefner \& M. Q. Zaman (Eds.), Schooling Islam: The Culture and Politics of Modern Education (pp. 172-198). Princeton: Princeton University Press.

Burhanuddin, J., \& Basri, H. (2003). Kiyai Abdullah Said: Sebuah Biografi. In Transformasi Otoritas Keagamaan: Pengalaman Islam Indonesia (pp. 292-316). Jakarta: PT. Gramedia Pustaka Utama.

Bustami, A. L. (2009). Kiai Politik, Politik Kiai. Malang: Pustaka Bayan.

Castle, L. (1966). Notes on the Islamic School at Gontor. Indonesia, 1, 30-45.

Damopoli, M. (2011). Pondok Modern IMMIM: Pencetak Muslim Modern. Jakarta: Rajawali Pers.

Dhofier, Z. (1999). The Pesantren Tradition: The Role of the Kiai in the Maintenance of Traditional Islam in Java. Tempe, Arizona: Program for Southeast Asian Studies, ASU.

Dhofier, Z. (2011). Tradisi Pesantren: Studi Pandangan Hidup Kiai Dan Visinya Mengenai Masa Depan Indonesia. Jakarta: LP3ES. 
Direktorat Jenderal Kelembagaan Agama Islam. (2008). Statistik Pendidikan Agama Dan Keagamaan (20062007). Retrieved from http://www.pendis.kemenag. go.id/file/dokumen/Analisis2008.pdf.

Direktorat Jenderal Pendidikan Islam. (2012a). Analisis Dan Interpretasi Data Pada Pondok Pesantren, Madrasah Diniyah (Madin), Taman Pendidikan Qurán (TPQ), Tahun Pelajaran 2011-2012. Retrieved from http://pendis. kemenag.go.id/index.php?a=artikel\&id2=analisis2011

Direktorat Jenderal Pendidikan Islam. (2012b). Tingkat kelulusan ujian nasional (UN) Madrasah Aliyah (MA) mencapai 99,50\%. Retrieved June 10, 2020, from http://pendis.kemenag.go.id/index. php?a=detilberita\&id=6718\#.XuLlpWozbPY.

Geertz, C. (1960a). The javanese kijaji: The changing role of a culturalbroker.ComparativeStudiesinSocietyandHistory. https://doi.org/10.1017/S0010417500000670

Geertz, C. (1960b). The Religion of Java. London: The Free Press of Glencoe.

Hady, A. (2012). Pesantren Gontor: Its Educational Reform and Contribution to the Creation of a Prominent Santri Network. The UNiversity of New South Wales.

Halim, W. (2018). Young Islamic preachers on Facebook: Pesantren As'adiyah and its engagement with social media. Indonesia and the Malay World. https://doi.org/ 10.1080/13639811.2018.1416796.

Hasan, N. (2008). Reformasi, Religious Diversity, and Islamic Radicalism after Suharto. Journal of Indonesian Social Sciences and Humanities, 1, 23-51. 
Hefner, R. W. (2009). Islamic Schools, Social Movements, and Democracy in Indonesia. In R. W. Hefner (Ed.), Making Modern Muslims: The Politics of Islamic Education in Southeast Asia (pp. 55-105). Honolulu: University of Hawaii Press.

Horikoshi, H. (1976). a Traditional Leader in a Time of Change : the 'Kijaji ' and 'Ulama ' in West Java. University of Illinois at Urban-Champaign.

Hourani, A. (1983). Arabic Thought in the Liberal Age 17981939. New York: Cambridge University Press.

Isbah, M. F. (2012). Religiously committed and prosperously developed: the survival of pesantren salaf in modern. Review of Indonesian and Malaysian Affairs, 46(1), 83104.

Isbah, M. F. (2019). How is Social Capital Converted to be Economic Capital? A Case Study from Pesantren ' s Socio-Economic Projects. Al Izzah: Jurnal Hasil-Hasil Penelitian, 14(1), 18-35.

Jackson, E., \& Parker, L. (2008). "Enriched with Knowledge": Modernisation, Islamisation and the Future of Islamic Education in Indonesia. RIMA: Review of Indonesian and Malaysian Affairs, 42(1), 21-53.

Karim, A. G. (2008). Pesantren in power : religious institutions and political recruitment in Sumenep, Madura. Review of Indonesian and Malaysian Affairs, 42(1), 157-184.

Karim, A. G. (2009). The Pesantren-based Ruling Elite in Sumenep in the Post-New Order Indonesia. Journal of Indonesian Islam, 03(01), 97-121.

Kumoro, I. (2012, May 24). Prosentase Kelulusan UN 2012 Meningkat. Kompas. 
Lukens-Bull, R. A. (2000). Teaching Morality: Javanese Islamic Education in a Globalizing Era. Journal of Arabic and Islamic Studies, 3(0), 26. https://doi.org/10.5617/ jais.4554.

Lukens-Bull, R. A. (2001). Two Sides of the Same Coin: Modernity and Tradition in Islamic Education in Indonesia. Anthropology <html_ent Glyph="@amp;" Ascii="\&amp;"/> Education Quarterly, 32(3), 350-372. https://doi.org/10.1525/aeq.2001.32.3.350.

Lukens-Bull, R. A. (2005). A Peaceful Jihad: Negotiating Identity and Modernity in Muslim Java. New York: Plagrave Macmillan.

Mas'ud, A. (2004). Intelektual Pesantren: Perhelatan Agama Dan Tradisi. Yogyakarta: LKiS.

Muhyiddin, \& Yulianto, A. (2017, November 30). Pertumbuhan Pesantren di Indonesia Dinilai Menakjubkan. Republika. Retrieved from https://www.republika.co.id/ berita/dunia-iaaslam/islam-nusantara/17/11/30/ p088lk396-pertumbuhan-pesantren-di-indonesiadinilai-menakjubkan.

Mulyati, S. (2002). The Educational Role of the Tariqa Qadiriyya Naqshbandiyya. McGill University.

Pohl, F. (2006). Islamic education and civil society: Reflections on the pesantren tradition in contemporary Indonesia. Comparative Education Review, 50(3), 389-409. https:// doi.org/10.1086/503882.

Sakai, M. (2012). Building a partnership for social service delivery in Indonesia: State and faith-based organisations. Australian Journal of Social Issues, 47(3), 373-388. https://doi.org/10.1002/j.1839-4655.2012. tb00254.x. 
Sakai, M. (2014). Establishing social justice through financial inclusivity: Islamic propagation by Islamic savings and credit cooperatives in Indonesia. TRaNS: Trans-Regional and -National Studies of Southeast Asia, 2(2), 201-222. https://doi.org/10.1017/trn.2014.4.

Shabir, M., \& Susilo, S. (2018). Muhammad Abduh's thought on muhammadiyah educational modernism: Tracing the influence in its early development. Qudus International Journal of Islamic Studies, 6(2), 127-159. https://doi. org/10.21043/qijis.v6i2.3813.

Solahudin, D. (2008). The Workshop for Morality: The Islamic Creativity of Pesantren Daarut Tauhid in Bandung, Java. https://doi.org/10.26530/oapen_459794.

Srimulyani, E. (2012). Women from Traditional Islamic Educational Institutions in Indonesia : Negotiating Public Spaces. https://doi.org/10.26530/oapen_418531.

Srimulyani, E. (2013). Islamic Schooling in Aceh: Change, Reform, and Local Context. Studia Islamika, 20(3).

Steenbrink, K. A. (1986). Pesantren, Madrasah, Sekolah: Pendidikan Islam dalam Kurun Modern. Jakarta: LP3ES.

Sticher, V. (2008). School Fees and Mainstreaming Education: Implication of the Government's Policy of Subsidizing Islamic Boarding Schools in Indonesia. International Journal of Pesantren Studies, 2(2), 139-170.

Subhan, A. (2006). Pesantren Hidayatullah: MadrasahPesantren Independen Bercorak Salafi. In J. Burhanudin \& D. Afrianty (Eds.), Mencetak Muslim Modern: Peta Pendidikan Islam Indonesia (pp. 203-240). Jakarta: PT. RajaGrafindo Persada. 
Tan, C. (2012). Islamic Education and Indoctrination: The Case in Indonesia. https://doi.org/10.1017/ CB09781107415324.004.

van Bruinessen, M. (1990). Kitab kuning; Books in Arabic script used in the Pesantren milieu; Comments on a new collection in the KITLV Library. Bijdragen Tot de Taal-, Land- En Volkenkunde / Journal of the Humanities and Social Sciences of Southeast Asia, 2(3), 226-269.

van Bruinessen, M. (1994). Pesantren and Kitab Kuning: Maintenance and Change in a tradition of religious learning. In W. Marschall (Ed.), Texts from the islands: Oral and written traditions of Indonesia and the Malay world (pp. 121-146). Berne: The University of Berne Institute of Ethnology,.

van Bruinessen, M. (1995). Kitab Kuning, Pesantren Dan Tarekat: Tradisi-Tradisi Islam Di Indonesia. Bandung: Mizan.

Wahid, D. (2014). Nurturing the Salafi Manhaj: A Study of Salafi Pesantrens in Contemporary Indonesia. Utrecht University.

Watson, C. W. (2005). A Popular Indonesian Preacher: The Significance of Aa Gymnastiar. The Journal of the Royal Anthropological Institute, 11(4), 773-792.

Yasin, M. A., \& Karyadi, F. (2011). Profil Pesantren Tebuireng. Jombang: Pustaka Tebuireng.

Yunus, M. (2008). Sejarah Pendidikan Islam di Indonesia. Jakarta: Mahmud Yunus Wadzurriyah. 
Zaini, A. (1998). Kiai Haji Abdul Wahid Hasyim: His contribution to Muslim educational reform and to Indonesian nationalism during the twentieth century. McGill University, McGill.

Zuhdi, M. (2006). Modernization of Indonesian Islamic schools 'curricula , 1945 - 2003. 10(4-5), 415-427. https://doi. org/10.1080/13603110500430765. 